\title{
Demand and Supply Analysis as a Basis for Jakarta Water Provision Planning
}

\author{
Nila Ardhianie ${ }^{1 *}$, Purwanto Purwanto ${ }^{2}$, and Kismartini ${ }^{3}$ \\ ${ }^{1}$ Doctorate Program of Environmental Science, School of Postgraduate Studies, Universitas \\ Diponegoro Semarang 50275, Indonesia \\ ${ }^{2}$ Doctorate Program of Environmental Science, School of Postgraduate Studies, Universitas \\ Diponegoro Semarang 50275, Indonesia \\ ${ }^{3}$ Departement of Public Administration, Universitas Diponegoro Semarang 50275, Indonesia
}

\begin{abstract}
Water provision is a necessity to reduce the risk of coronavirus contamination. Delivering water and sanitation services is now more critical than ever; the hygiene requirements increased water need. It is expected to grow even after the pandemic as a healthier habit that will become a routine for most of the population. In addition, economic activity is predicted to expand once the pandemic is under control. To safeguard sustainable water provision, it is critical for Jakarta to have comprehensive planning based on careful calculation of demand and supply. This is especially valid as climate change adds the pressures to water availability that have long been experienced by the capital, such as pollution, high reliance on groundwater, huge water supply from outside the region, lack of infrastructure, land subsidence, floods, and land-use change. This study aims to estimate the demand and supply for Jakarta's water comprehensively, cover all water sources inside and outside the capital, and develop a strategy based on the analysis produced. The strategy includes the need to focus on reducing, reusing and recycling approaches to local water available in Jakarta.
\end{abstract}

\section{Introduction}

Universal access to safe drinking water is a human right recognized by the United Nations Resolution 64/292 2010 [1].

Safe drinking water means "the water required for any personal or household use must be safe, free from microorganisms, chemicals, and radiological hazards that pose a threat to one's health," which is a vital human need; everyone must have access to safe drinking water. In Jakarta, most of the population still relies on groundwater without any processing for their daily needs.

Groundwater is the primary source because piped water services can only provide around 350 million $\mathrm{m}^{3}$ each year while the demand exceeds 1 billion $\mathrm{m}^{3}$. The heavy reliance on groundwater poses serious risks $[2,3,4]$. Overuse of groundwater causes environmental problems such as land subsidence, damage to buildings, increased risk of flooding and

\footnotetext{
* Corresponding author: nilaardhianie@gmail.com
} 
seawater intrusion. In addition, Jakarta's groundwater is prone to health problems, such as high Escherichia coli contamination.

In populated urban areas like Jakarta, the safest provision of drinking water may be through a closed piped water system channelled to residents' connections. A closed system can reduce the risk of contamination. It has been reported that only $4 \%$ of Jakarta has access to sewerage, with $96 \%$ or over 9.2 million people, with no wastewater management or treatment systems. Most sewerage is disconnected and discharged directly to surface waters [5]. This sewerage can contaminate not only the surface but also the groundwater.

The water quality test by the Environment Agency on 267 samples of groundwater in five areas of the Capital City took place from March 22 to May 25, 2018, shows that 64.6 per cent of the samples were contaminated with detergent and Escherichia coli above the quality standard threshold [6]. Several other research also shows the same conclusion [7, 8, 9]. With the current sewer network covering only $2 \%$ of Jakarta, household black and grey water are discharged to the septic tank. The septic tank is often not maintained, resulting in leakage and spread contamination. In many cases, the septic tank is built too close to the water sources due to the narrow space of the land $[10,11]$.

Therefore, the availability of piped water services in Jakarta is an important and urgent matter. The World Health Organization (WHO) notes that improving access to piped water in urban areas can drastically reduce deaths from infection. Lack of access to safe drinking water, on the other hand, has left "Nearly half of urban residents in Africa, Asia and Latin America suffer from at least one disease caused by a lack of clean water and sanitation." Additionally, every dollar invested in water and sanitation provides a return on reduced medical costs of US \$ 4.3 [12].

This study aims to produce a water supply and demand analysis for Jakarta, the capital city of Indonesia, inhabited by 11.058 .944 people in 2020. Jakarta so far does not have an exact calculation of demand and supply due to a limited data management system. The privatization of the water service provision system since 1998 might contribute to this concern as data are not public and difficult to access. With the limited data available, this study aims to provide the best outcome to estimate the water balance for Jakarta covers water sources coming from inside and outside the capital and the demand based on the normal and common use of water.

\section{Method}

This study estimates the demand and supply analysis using a simple mathematical equation as follow:

\section{Domestic demand + Commercial demand $=$ Local groundwater + local surface water + import surface water $^{(1)}$}

Domestic demand is the total amount of population water consumption based on per capita average water use.

Commercial demand is the total amount of non-domestic water use.

Local groundwater is the total amount of underground water (shallow and deep) use.

Local surface water is the total amount of water use from rivers in Jakarta.

Import surface water is the total amount of water diverted from outside Jakarta.

The total amount of water supply consists of surface water, groundwater, wastewater reuse and rainwater utilization. Jakarta, until today, has not utilized wastewater for clean water production, and the people do not use the river's water. This equation calculates domestic water demand by multiplying the number of populations with daily everyday water 
use based on PAM Jaya historical data. The estimation for commercial demand is $30 \%$ of domestic; the percentage is also based on PAM Jaya historical data on domestic and commercial consumption. The amount of bulk water supply for piped water is taken from PAM Jaya data. The groundwater supply is the total water needs deducted with the total supply for piped water consumption. The resulting estimation needs to be used as the basis for Jakarta's water supply provision planning.

\section{Discussion}

In 2019 Jakarta population is $11,058,944$ [15]. Estimating the above method shows that Jakarta's water needs are 1.07 billion $\mathrm{m}^{3}$, and $34 \%$ of it is supplied by piped water using surface water (PAM Jaya) and the remaining 66\% from groundwater. Table 1 shows the demand and supplies calculation for 2019 , including the water use by $30 \%$ daily commuters and commercial demand of $30 \%$ domestic consumption with standard water use is 150 litres/resident/day and 125 litres/commuter/day. The total demand is 1,07 billion cubic meters consisting of domestic $\left(725 \mathrm{~m}^{3}\right)$ and commercial $\left(341 \mathrm{~m}^{3}\right)$. This result indicates that Jakarta has a huge dependence on groundwater coming from the Jakarta groundwater basin.

Tabel 1. Error! No text of specified style in document. Jakarta Water Balance 2019.

\begin{tabular}{|c|c|c|}
\hline & Population & Volume \\
\hline Demand & & \\
\hline Residents & 11.058 .944 & 605.477 .184 \\
\hline Commuters & 3.317 .683 & 119.436 .588 \\
\hline Domestic & & 724.913 .772 \\
\hline Commercial & & 341.135 .892 \\
\hline Total demand & & $\mathbf{1 . 0 6 6 . 0 4 9 . 6 6 4}$ \\
\hline Supply & & $(34 \%) 362.626 .303$ \\
\hline Piped water & & $(66 \%) 703.423 .361$ \\
\hline Groundwater & & 1.066 .049 .664 \\
\hline Total supply & & \\
\hline
\end{tabular}




\section{Water sources}

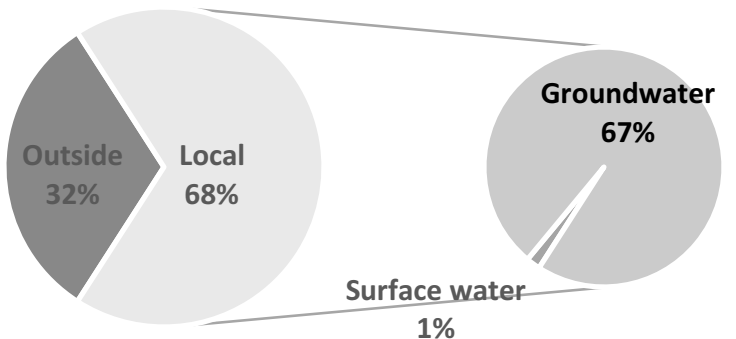

Fig. 1. Jakarta water sources.

Jakarta water supplies come from local and outside the capital. Imported water is used for piped water production, and most of it (96\%) is from neighbouring provinces: the Jatiluhur Dam in Purwakarta and Tangerang in West Java Province (see Table 2). Bulk water from Jatiluhur is transported using a $72 \mathrm{~km}$ open channel, while water from Tangerang Regency is transported using a 30-kilometre pipeline. In total, $31,8 \%$ of piped water is imported water, and local water serves $1,3 \%$ piped water and $66,9 \%$ for wells using deep or shallow groundwater. The composition of local and import water is $68.2 \%$ taking from Jakarta, a river basin, and groundwater basin and $31.8 \%$ is obtained from outside Jakarta.

Table 2. Water sources for piped water in Jakarta.

\begin{tabular}{|c|c|c|c|c|}
\hline No & Water sources & Location & Installation unit & $\begin{array}{l}\text { Capacity } \\
\text { (I/s) }\end{array}$ \\
\hline & PT Palyja (West) & & & \\
\hline & Clean water & & & \\
\hline 1 & PDAM Tangerang & Kab. Tangerang & DCR-4 & 2.000 \\
\hline 2 & PDAM Tangerang & Kab. Tangerang & DCR-5 & 800 \\
\hline \multirow[t]{2}{*}{3} & PDAM Tangerang & Kab. Tangerang & Cengkareng & 2.300 \\
\hline & Air Bersih/Produksi & & & \\
\hline \multirow[t]{3}{*}{4} & \multirow{3}{*}{$\begin{array}{l}\text { Banjir Kanal Barat \& Tarum } \\
\text { Barat }\end{array}$} & \multirow[t]{3}{*}{ Central Jakarta - Jatiluhur } & Pejompongan I & 2.000 \\
\hline & & & Pejompongan II & 3.600 \\
\hline & & & Hutan Kota & 150 \\
\hline 5 & Kali Krukut & South Jakarta & Cilandak & 400 \\
\hline \multirow[t]{3}{*}{6} & Kali Pesanggrahan & West Jakarta & Cikokol & 75 \\
\hline & PT Aetra (East) & & & \\
\hline & Bulk water & & & \\
\hline 7 & Irigasi River/West Tarum & Malang River - Jatiluhur & Buaran I I & 2.000 \\
\hline
\end{tabular}




\begin{tabular}{|l|l|l|l|r|}
\hline & & & Buaran II & 3.000 \\
\hline 8 & Irigasi River/West Tarum & Malang River - Jatiluhur & IPA Pulogadung & 4.000 \\
\hline \multicolumn{2}{|l|}{ Total capacity } & $\mathbf{2 0 . 3 2 5}$ \\
\hline
\end{tabular}

Source: PAM Jaya 2021

\section{Planning for water provision}

The The above calculations show that Jakarta's groundwater basin supplies most of the total water needs. As a direct consequence of that reality, the city must plan its water provision system carefully. It should prioritize managing the groundwater basin better and increase its quality. People usually use groundwater without any treatment, and they use it directly; if the water is contaminated, the user is also potentially exposed to contaminants. Groundwater used directly without being processed can have health risks since it contains harmful chemicals and microorganisms. Therefore, priority should be given to pollution control and wastewater treatment to prevent polluted water from contaminating the groundwater system. Improving access to sanitation can help safeguard water quality from domestic water pollution.

From the supply side, efforts need to be made to 1) reduce pollution so that dirty water contaminating the groundwater system can be reduced, 2) reduce groundwater use and increase surface water supply, 3) use wastewater as a source of raw water. Demand management needs to be done through socio-political measures - the legal framework to promote the demand management measures and water conservation, public education, and awareness building.

The high dependence on groundwater endangers the health of the population, the environment, and the economy. For the environment, groundwater extracted more than safe yield causes land subsidence, which impacts the risk of flooding and infrastructure damage. Groundwater intake should be reduced and replaced with surface water by reducing piped water leakage, treating river water, lakes and lakes in Jakarta, and building water reservoirs in the appropriate areas.

Utilizing wastewater for water sources also needs to be a prioritized program for the government to increase the local water supply. Currently, sewerage service only covers $4 \%$ of the population. Every day, Jakarta's massive amount of wastewater infiltrates enters directly into water bodies and pollutes the surface and groundwater. Programs to improve access to centralized wastewater services need to be seriously enhanced. Communities need to understand the benefits of processing wastewater and not dumping it directly into water bodies. Currently, Jakarta has a large wastewater treatment project, namely the "Jakarta Sewerage Development Project" (JSDP), a project collaboration between the Directorate General of Housing Development, Ministry of Public Works and Public Housing (PUPR) and Japan International Cooperation Agency (JICA). Jakarta's wastewater treatment capacity will increase significantly when this project is completed. The results from wastewater treatment can also be an alternative source of raw water for toilets, parks, and other necessities. Table 1.3. shows the water treatment capacity developed by JSDP. The project supports the Provincial Government of the Special Capital Region of Jakarta (DKI Jakarta) to build domestic wastewater treatment plants and pipelines with a capacity of around 2.5 million cubic meters per day spread in 14 zones.

Jakarta already has Governor Decree No. 45/1992, which stipulates that every building in an area with a sewage pipe installed must dispose of its wastewater into the pipe through a parcel connection pipe. The provision of a centralized piping system/wastewater management facility can reduce groundwater and surface water contamination. By 
discharging wastewater into pipelines, the grey and black water will flow through a piping system to a treatment plant treated to meet quality standards for disposal to the receiving water body (river).

To increase the quantity of water that can be utilized, it is necessary to build a rainwater storage capacity using light materials to reduce soil loads and increase water treatment facilities' capacity through decentralized and centralized processing. It is necessary to identify rivers or reservoirs that can become water sources for one area, equipped with mini plants and rainwater storage made of light materials. Supported with the operation of a largescale sanitation project in Jakarta, the potential for water that can be utilized from rivers and reservoirs will increase. By developing these programs, Jakarta can gradually build water security and reduce its dependence on imported water.

\section{Conclusion}

Urban water management has two primary approaches. The conventional one is supplydriven; it handles the growing need by increasing water supply, searching for additional supplies, and building new facilities to process bulk water into clean and safe water. The approach has led to over-consumption and some environmental issues, making it unsustainable. Another approach is trying to manage the demand aspect and considered as more sustainable.

Based on the analysis of Jakarta's water supply and demand, it is known that Jakarta's water supply comes from local and imported water. The composition of local water from groundwater is higher than imported water sourced from surface water. Therefore, the direction of planning for Jakarta's water supply should be focused on local water management. Water supply planning needs to be directed at managing two aspects, namely demand and supply. From the supply aspect, efforts need to be made to 1) reduce pollution so that dirty water entering the groundwater system can be reduced, 2) reduce groundwater use and increase surface water supply, 3) use wastewater as a source of raw water. Demand management needs to be done through socio-political measures - the legal framework to promote the demand management measures and water conservation, public education and awareness building.

\section{Reference}

1. United Nations General Assembly, The Human Rights to Water and Sanitation. 2010.

2. T. Neise, "Firms' adaptation strategies to floods and their potential implication on regional economic development-Insights from Jakarta and Semarang, Indonesia The effect of natural disasters on FDI attraction-a sector-based analysis over time and space View project," University of Cologne, 2019.

3. D. Sarah, L. M. Hutasoit, R. M. Delinom, I. A. Sadisun, dan T. Wirabuana, "A physical study of the effect of groundwater salinity on the compressibility of the Semarang-Demak aquitard, Java Island," Geosci., vol. 8, no. 4, page 12-14, 2018.

4. S. Koop, "Groundwater depletion in Jakarta Metropolitan Region," page 2012-2015, 2014.

5. P. Luo et al., "Water quality trend assessment in Jakarta: A rapidly growing Asian megacity," PLoS One, vol. 14, no. 7, 2019.

6. Dinas Lingkungan Hidup Jakarta, “Air Tanah di Jakarta Sudah Tercemar Detergen Dan E.coli," 2018. [Daring]. Tersedia pada: http://www.pdamtirtabenteng.co.id/berita/air-tanah-di-jakarta-sudah-tercemar- 
detergen-dan-ecoli. [Diakses: 27-Apr-2021].

7. R. Padawangi dan M. Douglass, "Water, water everywhere: Toward participatory solutions to chronic urban flooding in Jakarta," Pac. Aff., vol. 88, no. 3, page 517-550, Sep 2015.

8. M. Kooy dan C. T. Walter, "Towards a situated urban political ecology analysis of packaged drinking water supply," Water (Switzerland), vol. 11, no. 2, Jan 2019.

9. D. E. Irawan, H. Silaen, P. Sumintadireja, R. F. Lubis, B. Brahmantyo, dan D. J. Puradimaja, "Groundwater-surface water interactions of Ciliwung River streams, segment Bogor-Jakarta, Indonesia," Environ. Earth Sci., vol. 73, no. 3, page 1295$1302,2015$.

10. K. Shaad dan P. Burlando, "Monitoring and modeling of shallow groundwater dynamics in urban context: The case study of Jakarta," J. Hydrol., vol. 573, page 1046-1056, Jun 2019.

11. L. Dsikowitzky et al., "Transport of pollution from the megacity Jakarta into the ocean: Insights from organic pollutant mass fluxes along the Ciliwung River," Estuar. Coast. Shelf Sci., vol. 215, page 219-228, Des 2018.

12. WHO, "Every dollar invested in water, sanitation brings a four-fold return in costs UN || UN News," 2014. [Daring]. Tersedia pada:

https://news.un.org/en/story/2014/11/484032-every-dollar-invested-water-sanitationbrings-four-fold-return-costs-un. [Diakses: 27-Apr-2021].

13. M. F. Reyes Perez, Water supply and demand management in the galápagos: A case study of Santa Cruz Island. 2017.

14. T. R. Gurung, R. A. Stewart, C. D. Beal, dan A. K. Sharma, "Smart meter enabled water end-use demand data: Platform for the enhanced infrastructure planning of contemporary urban water-supply networks," J. Clean. Prod., vol. 87, no. 1, page 642-654, 2015.

15. Badan Pusat Statistik DKI Jakarta, "Provinsi DKI Jakarta Dalam Angka 2020," Provinsi DKI Jakarta Dalam Angka 2020, 2020.

16. Republika, "Pemakaian harian Jakarta 150 liter.” Republika, 2019. 